\title{
Field and Greenhouse Response of Red Raspberry Genotypes to Root Rot
}

\author{
Wendy K. Hoashi-Erhardt and Patrick P. Moore ${ }^{1}$ \\ Department of Horticulture and Landscape Architecture, Puyallup Research \\ and Extension Center, Washington State University, 7612 Pioneer Way East, \\ Puyallup, WA 98371
}

\section{Gwenyth E. Windom and Peter R. Bristow \\ Department of Plant Pathology, Puyallup Research and Extension Center, Washington State University, Puyallup Research and Extension Center, 7612 Pioneer Way East, Puyallup, WA 98371}

Additional index words. Rubus idaeus, Phytophthora fragariae var. rubi, disease assay, disease resistance, genotype reaction

\begin{abstract}
Red raspberry genotypes (Rubus idaeus $\mathrm{L}$.) were evaluated for resistance to root rot at two field sites in Washington state and in a greenhouse study. Thirteen raspberry genotypes were planted in two field sites naturally infested with Phytophthora fragariae var. rubi Wilcox and Duncan and evaluated over 3 years for growth and symptom expression. In greenhouse pot tests, 14 genotypes were inoculated with an isolate of $P$. fragariae var. rubi at three inoculum levels and evaluated for growth, root color, and symptom expression using a 1 to 4 rating scale. Eleven of the 14 cultivars were found to be susceptible or very susceptible to root rot in the field and greenhouse. 'Summit' and 'Newburgh' possessed high levels of resistance to the pathogen. 'Cascade Bounty' also showed high resistance to root rot in the greenhouse, but confirmation from a field study is needed. Subjective root ratings of greenhouse-grown plants correlated well with measurements of cane numbers and cane infection in the field. The greenhouse tests were useful in identifying resistant genotypes and very susceptible genotypes but did not always match field results. Observation of at least 3 years in the field was necessary to compare relative reaction with root rot among genotypes.
\end{abstract}

Root rot caused by the persistent soilborne oomycete Phytophthora fragariae var. rubi is a serious disease of red raspberry in the Pacific Northwest and worldwide. It can decrease the vigor and yield of raspberry plantings and require accelerated replanting cycles, especially for susceptible cultivars. The pathogen thrives in cool soils that regularly experience prolonged periods of high soil moisture (Wilcox, 1989). Field symptoms of diseased raspberry plants often include reduced primocane emergence, wilted and chlorotic canes, and necrotic primocane lesions that spread upward from infected roots (Kennedy and Duncan, 1991; Wilcox, 1989). Phytophthora fragariae var. rubi is considered the dominant disease agent of root rot in red raspberries (Wilcox et al., 1993), although several other soilborne pathogens may contribute to a disease complex affecting raspberries (Schilder, 2007; You et al., 2006).

\footnotetext{
Received for publication 27 Dec. 2007. Accepted for publication 24 Apr. 2008.

This research was partially funded by the Northwest Center for Small Fruit Research, Washington State University, College of Agricultural, Human and Natural Resource Sciences, Pullman, WA, Project No. 0252 and 0640.

We thank Marc Evans, Professor of Statistics, Washington State University, for statistical advice. ${ }^{1}$ To whom reprint requests should be addressed; e-mail moorepp@wsu.edu
}

Integrated management of root rot in raspberry plantings can include the use of raised beds, soil solarization, preplant incorporation of gypsum or calcitic lime, application of registered fungicides, and the planting of resistant cultivars (Heiberg, 1999; Maloney et al., 2005; Pinkerton et al., 2002; Wilcox et al., 1999b). Of these, resistant cultivars are critical for long-term control. In a study examining the effect of cultivar, bed height, biological control treatment, fungicide (metalaxyl), and straw mulch on raspberry growth and disease symptoms, cultivar susceptibility was the most important factor (Wilcox et al., 1999b). Both raised beds and metalaxyl application provided slight benefit to the resistant cultivar Newburgh but did not improve growth or yield outcomes for the susceptible cultivar Titan (Wilcox et al., 1999b).

A few cultivars are resistant to root rot such as 'Newburgh' and 'Latham', but most commercial cultivars are susceptible to root rot and eventually show disease symptoms (Pattison et al., 2004). These include 'Meeker', which accounts for more than $70 \%$ of raspberry plantings in the Pacific Northwest (Washington Red Raspberry Commission, 2004), and 'Willamette' (Barritt et al., 1981). Several new cultivars adapted to the Pacific Northwest have unknown responses to root rot. A major goal of raspberry breeding programs is to combine root rot resistance with superior horticultural traits in new cultivars; identifying genetically resistant material is advantageous for commercial production and breeding efforts.
Field evaluations of raspberry genotypes for resistance to $P$. fragariae var. rubi have the advantage of being similar to the conditions of commercial raspberry plantings. However, field evaluations are time-consuming, as symptoms may take several years to develop, and soil conditions and disease pressure may not be uniform. Greenhouse pot tests (Bristow et al., 1988; Kennedy and Duncan, 1991; Laun and Zinkernagel, 1993; Wilcox et al., 1999a) and hydroponic culture systems (Pattison et al., 2004) can provide greater control of environment and disease pressure, but typically use small plants that may not respond in the same manner as mature, well-established plants under field conditions. 'Cowichan' was moderately resistant to root rot in a greenhouse pot test but was shown to be susceptible in subsequent field plantings (Kempler et al., 2005). This raises concerns about the applicability of greenhouse results to field performance. The objective of this research was to evaluate the relative susceptibility of red raspberry genotypes to root rot caused by $P$. fragariae var. rubi in field and greenhouse conditions and to compare the responses.

\section{Materials and Methods}

Plant material. All plants were tissueculture propagated and transplanted into a potting mix of peat, sand, and pumice ( $4: 4: 3$ by volume plus fertilizer amendments) and grown under standard greenhouse conditions before field establishment or use in the greenhouse study.

Field experiments. The raspberry genotypes were tested at the Washington State University Puyallup Research and Extension Center (Puyallup) and Washington State University Vancouver Research and Extension Unit (Vancouver), both of which had been previously planted to raspberry and were naturally infested with $P$. fragariae var. rubi. Puyallup was sampled as part of a regional survey and the presence of $P$. fragariae var. rubi confirmed by an independent laboratory (Washington State University, 2006). The soil at Vancouver was a Gee silt loam and the soil at Puyallup was a Sultan silt loam.

Before planting, soils at both locations were tilled to a depth of $15 \mathrm{~cm}$. Plants were set in flat beds rather than raised beds to encourage disease development. Thirteen cultivars and advanced selections were planted in both sites in a randomized complete block design. Cultivars were selected for inclusion in the study based on suitability to regional growing conditions. 'Newburgh' and 'Summit' were included as resistant cultivars and 'Malahat' and 'Kitsilano' as susceptible cultivars. 'Cascade Bounty' was omitted from both field plantings. All cultivars were floricane fruiting except for 'Summit'.

Tissue-culture propagated plants of each genotype were planted in six replicates in July 2003 at Puyallup. Plants were set at 1-m in-row spacing with a single plant per plot along one row running north to south. 
Tissue-culture propagated red raspberry plants were planted in four replicates in July 2003 at Vancouver. Eight plants were set $0.7 \mathrm{~m}$ apart in $5.6-\mathrm{m}$ plots. Within the rows, plots were separated by $3.2 \mathrm{~m}$. Between-row spacing was $3 \mathrm{~m}$.

Overhead irrigation was used to establish the planting at Puyallup and Vancouver. During three cropping seasons, Puyallup plots received no irrigation, and the Vancouver plots received drip irrigation. Annual rainfall between 760 and $1010 \mathrm{~mm}$ during the experiment was typical for the area and similar in the two locations except in 2006, when rainfall exceeded $1300 \mathrm{~mm}$ in Vancouver. Fruiting canes were pruned at the end of each cropping season, and primocanes were tied to trellises. Plots were cultivated between rows as needed to reduce weed growth.

In July 2004, 2005, and 2006, the number of healthy and infected primocanes was counted for each plot at Puyallup and Vancouver. The Vancouver cane numbers were divided by 8 to obtain measurements on a per-hill basis. Plots with no canes were considered to have $100 \%$ infection. In Dec. 2004, 2005, and 2006, the height of up to 25 primocanes per plot at Puyallup and up to 50 canes per plot at Vancouver were measured and used to calculate average cane height. The numbers of healthy and infected canes were added to give the total number of canes. Percent infection was calculated by dividing the number of infected canes by the total number of canes. Fruit was not harvested from the plots.

Greenhouse experiments. Genotypes were evaluated in two separate greenhouse trials using the method of Bristow et al. (1988). Phytophthora fragariae var. rubi (ATCC Culture No. 16184), originally isolated from the roots of an infected 'Canby' raspberry plant grown at Vancouver (Converse and Schwartze, 1968), was grown in still culture in clarified V-8 juice broth [V-8 juice (Campbell Soup Co., Camden, NJ), 163 $\mathrm{mL}$; $\mathrm{CaCO}_{3}, 2.52 \mathrm{~g}$; distilled water, $200 \mathrm{~mL}$; centrifuged at $1000 g_{\mathrm{n}}$ for $15 \mathrm{~min}$ to clarify, supernatant diluted to $2.8 \mathrm{~L}$ and autoclaved]. Cultures were incubated at room temperature $\left(23 \pm 1.5^{\circ} \mathrm{C}\right)$ for 10 to $21 \mathrm{~d}$. Mycelial mats were collected in a Buchner funnel and washed twice with tap water maintained at 17 to $20{ }^{\circ} \mathrm{C}$. Excess moisture was pressed from the washed mats with a spatula before weighing. Mats were transferred to a Waring (New York, NY) blender with adequate water for macerating and pulsed twice for $10 \mathrm{~s}$ per pulse with a 10 -s pause between pulses.

A suspension was prepared of $20 \mathrm{~g}$ wet mycelium per $100 \mathrm{~mL}$ tap water. Appropriate dilution gave inoculum suspensions of 200 , 50 , and $10 \mathrm{mg}$ mycelium per milliliter of water. Control plants were inoculated with water only. A syringe fitted with an 18-gauge cannula was used to inject the inoculum. The cannula was inserted into the growing medium to a depth of $\approx 2.5 \mathrm{~cm}$ at sites $\approx 1 \mathrm{~cm}$ away from the stem, and the suspension injected as the cannula was slowly withdrawn. One milliliter of mycelial suspension was injected into four sites in the soil around each plant for a total of $4 \mathrm{~mL}$ suspension per pot.

The greenhouse inoculation study was conducted in two tests, each a two-way factorial arrangement on a randomized complete block design with cultivar and inoculum concentration as treatment factors. There were four replications in each study. Four to 5 weeks after being transferred from tissue culture into potting mix in $5.7 \times 5 \times 5.7-\mathrm{cm}$ plastic pots, plants of 11 genotypes were inoculated with water or 10,50 , or 200 $\mathrm{mg} \cdot \mathrm{mL}^{-1}$ mycelium suspension in Feb. 2005. In Apr. 2005, five genotypes were tested in the same manner. 'Newburgh' and 'Meeker' were included in both tests. At the time of inoculation, February plants had four to six true leaves, while April plants had three to five true leaves.

Plants were maintained in a temperaturecontrolled greenhouse $\left(19 \pm 3{ }^{\circ} \mathrm{C}\right)$ separated by inoculum treatment and replicate in tubs containing $1 \mathrm{~cm}$ of water. The plants were examined every 5 to $7 \mathrm{~d}$ for symptoms. Three weeks after inoculation, plants were removed from pots. After washing the roots, the plants were evaluated for root rating and shoot rating, root dry weight, shoot dry weight, and increase in shoot growth. Color value of freshly washed roots was measured by a Minolta Chroma Meter CR200b (Minolta, Ramsey, N.J) and recorded as L*. Roots were examined microscopically for the presence of oospores at the end of the evaluation period to verify successful inoculation with the pathogen.

Statistical analysis. Field data were analyzed for each location using a repeated measures analysis of variance (ANOVA). Significance of the repeated measures factor and its interaction with genotype was tested with the Huynh-Feldt adjusted probability value to account for lack of sphericity in the repeated measures. ANOVA for each location was also performed separately by year, and differences in genotype means were compared using Tukey's honestly significant differences (HSD) test. Significance of treatment factors and their interaction was tested at $P<0.05$. Correlation coefficients between field variables were determined within and between locations. Greenhouse data were analyzed using general linear models, and correlation coefficients of greenhouse variables were calculated. Genotype means of field and greenhouse variables were compared in correlation analysis. All statistical analyses were performed with SAS 9.1 software (SAS Institute, Cary, NC).

\section{Results}

Field experiments. The effect of genotype was highly significant for percent infection, total cane number, and cane height (data not shown) in both locations for each year $(P<$ 0.01 ) with the exception of a nonsignificant effect for percent infection at Vancouver in 2004 (Table 1). These results were confirmed by repeated measures ANOVA, which indicated an overall significant effect of genotype for percent infection, total cane number, and cane height at both Puyallup and Vancouver $(P<0.0001)$. There was also a significant effect of year $(P<0.0001)$ and genotypeby-year interaction $(P<0.001)$ for the three variables in both locations.

The genotype $\times$ year interactions were reflected in field response trends over time. Characteristic field responses of a resistant cultivar (Summit), a susceptible cultivar (Meeker), and a very susceptible cultivar (Malahat) are shown in Figure 1 as examples. Time trends for cane number and percent infection in Vancouver generally resembled those at Puyallup, though plot variability and low numbers of surviving canes in Vancouver gave rise to different percent infection trends for four genotypes at the two locations.

Resistance in 'Summit' was confirmed by infection rates less than $10 \%$ in each year and relatively stable cane numbers and cane heights in Years 2 and 3. 'Newburgh' differed from 'Summit' by having infection rates above $10 \%$ and a sharper decline in total cane number at Vancouver in 2006. In contrast to 'Summit', 'Malahat' had steadily declining cane numbers and infection rates of $20 \%$ or greater that increased sharply from 2004 to 2006. 'Kitsilano', 'Cowichan', WSU 1226, and 'Cascade Nectar' resembled 'Malahat' with low cane survival and infection rates generally above $50 \%$ in 2006 . The remaining genotypes with intermediate responses were identified as susceptible. Two of these cultivars, Cascade Dawn and Cascade Delight, had very vigorous growth in 2004 and 2005, which seemed to indicate root rot resistance. However, means of infected canes above $10 \%$ and their pattern of reduced cane number and cane height between the second and third years revealed susceptibility to the disease.

Genotype means for percent infection were strongly correlated between the two locations in 2004 and 2005 (Table 2). Total cane number means were closely correlated in 2005. The weaker but significant correlations in 2006 may reflect the plot variability at Vancouver.

Greenhouse studies. There was a significant effect of cultivar $(P<0.0001)$ for root rating and shoot rating in the February study (Table 3). Overall, 'Newburgh' and 'Cascade Bounty' had fewer root rot symptoms than all of the other cultivars tested except 'Cascade Delight'. 'Cascade Delight' had root and shoot ratings similar to 'Newburgh', a resistant cultivar, when tested at the 50 $\mathrm{mg} \cdot \mathrm{mL}^{-1}$ inoculum level, but had higher ratings at the 10 and $200 \mathrm{mg} \cdot \mathrm{mL}^{-1}$ levels (data not shown). 'Kitsilano', 'Malahat', and 'Cascade Dawn' had high root and shoot ratings at all inoculum levels.

There was also a significant effect of cultivar $(P<0.0001)$ for root rating and shoot rating in the April study (Table 3). 'Summit' and 'Newburgh' had much lower root and shoot ratings than 'Meeker', 'Cascade Nectar', and 'Cowichan'. Ratings were higher overall in the April study compared with the 
Table 1. Evaluation of growth per hill of 13 genotypes of red raspberry on two sites naturally infested with Phytophthora fragariae var. rubi in Washington state.

\begin{tabular}{|c|c|c|c|c|c|c|}
\hline \multirow[b]{2}{*}{ Cultivar } & \multicolumn{3}{|c|}{ Infection (\%) } & \multicolumn{3}{|c|}{ Total canes (no.) } \\
\hline & 2004 & 2005 & 2006 & 2004 & 2005 & 2006 \\
\hline \multicolumn{7}{|l|}{$\overline{\text { Puyallup }}$} \\
\hline Summit & 0 & 6 & 4 & 13 & 43 & 37 \\
\hline Cascade Dawn & 4 & 19 & 19 & 54 & 67 & 41 \\
\hline Cascade Delight & 2 & 18 & 20 & 18 & 31 & 27 \\
\hline Newburgh & 0 & 12 & 10 & 33 & 57 & 50 \\
\hline WSU 1112 & 4 & 18 & 34 & 26 & 40 & 27 \\
\hline Tulameen & 1 & 25 & 33 & 25 & 30 & 16 \\
\hline Willamette & 6 & 32 & 48 & 36 & 48 & 9 \\
\hline Meeker & 1 & 16 & 48 & 28 & 43 & 14 \\
\hline WSU 1226 & 12 & 35 & 58 & 17 & 13 & 6 \\
\hline Cowichan & 11 & 40 & 50 & 44 & 21 & 3 \\
\hline Malahat & 21 & 69 & 100 & 28 & 13 & 0 \\
\hline Kitsilano & 10 & 42 & 83 & 19 & 13 & 2 \\
\hline Cascade Nectar & 7 & 30 & 49 & 31 & 37 & 15 \\
\hline $\mathrm{HSD}^{\mathrm{z}}$ & 16 & 41 & 58 & 17 & 19 & 20 \\
\hline Mean & 6 & 28 & 43 & 29 & 35 & 19 \\
\hline \multicolumn{7}{|l|}{ Vancouver } \\
\hline Summit & 0.2 & 1 & 3 & 13 & 26 & 25 \\
\hline Cascade Dawn & 1 & 17 & 19 & 19 & 24 & 7 \\
\hline Cascade Delight & 1 & 14 & 20 & 12 & 17 & 7 \\
\hline Newburgh & 0.2 & 5 & 18 & 12 & 20 & 6 \\
\hline WSU 1112 & 8 & 26 & 30 & 14 & 13 & 4 \\
\hline Tulameen & 4 & 19 & 31 & 7 & 5 & 1 \\
\hline Willamette & 12 & 50 & 0 & 22 & 19 & 1 \\
\hline Meeker & 8 & $53 /$ & 25 & 11 & 14 & 1 \\
\hline WSU 1226 & 19 & 36 & 53 & 2 & 1 & 0.3 \\
\hline Cowichan & 10 & 56 & 50 & 14 & 13 & 0.3 \\
\hline Malahat & 27 & 95 & 50 & 2 & 0.2 & 0.1 \\
\hline Kitsilano & 12 & 56 & 75 & 2 & 1 & 0.03 \\
\hline Cascade Nectar & 23 & 38 & 100 & 4 & 2 & 0 \\
\hline HSD & NS & 45 & 87 & 15 & 12 & 8 \\
\hline Mean & 10 & 36 & 36 & 10 & 12 & 4 \\
\hline
\end{tabular}

${ }^{\mathrm{z}}$ Comparisons within location and year that exceed Tukey's honestly significant difference (HSD) are significantly different at $P=0.05$.

${ }^{\mathrm{N}}$ Nonsignificant.
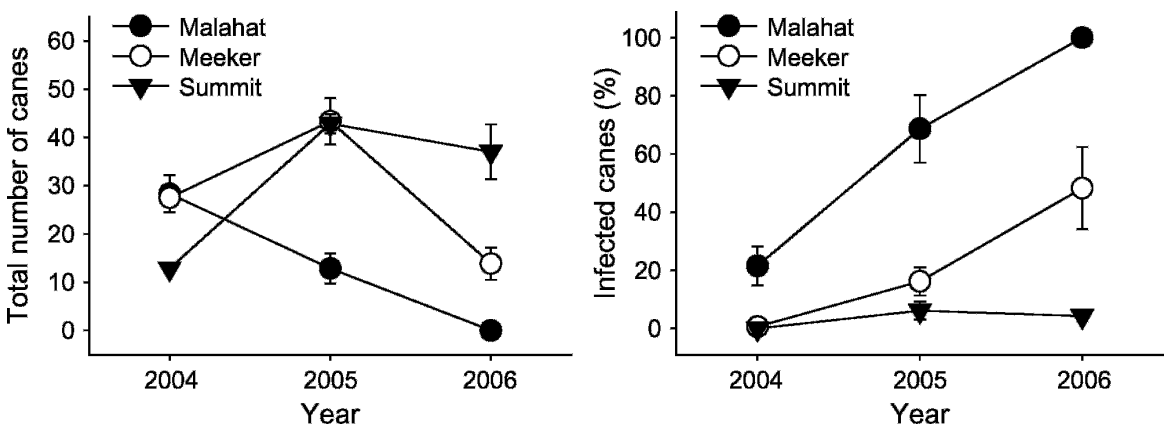

Fig. 1. Time response of three cultivars to field root rot conditions over 3 years at Puyallup ( \pm SE, $n=6$ ).

Table 2. Correlation coefficients $(r)$ between locations (Puyallup and Vancouver) of field criteria used to evaluate root rot in 13 raspberry genotypes $(\mathrm{n}=13)$.

\begin{tabular}{llll}
\hline Criterion & 2004 & 2005 & 2006 \\
\hline Total cane & & & \\
$\quad$ number & 0.55 & $0.80^{* *}$ & $0.64^{*}$ \\
Percent infection & $0.85^{* * *}$ & $0.89^{* * *}$ & $0.59^{*}$ \\
Cane height & 0.35 & $0.61^{*}$ & $0.69^{* *}$ \\
\hline${ }^{*}, * *,{ }^{* *}$ Significant at $P \leq 0.05,0.01$, or 0.001, re- \\
spectively.
\end{tabular}

February study, which may be the result of smaller plant size at the time of inoculation in the April study. 'Newburgh' had ratings similar to 'Summit' at the lowest inoculum
Genotype means of root rating in the February study had variable relationships with means of field variables in 2006 (Table $4)$. The correlation coefficient was highest between the $50 \mathrm{mg} \cdot \mathrm{mL}^{-1}$ root ratings and percent infection at Puyallup. Root rating means at the 10 and $200 \mathrm{mg} \cdot \mathrm{mL}^{-1}$ inoculation levels showed much weaker correlations with genotype means of field parameters. Correlations between greenhouse variables and field variables were generally higher at Puyallup than at Vancouver. Other evaluation criteria used in the greenhouse study such as root dry weight, shoot dry weight, and shoot growth did not correlate strongly with field study results (data not shown).

\section{Discussion}

The only cultivar to exhibit excellent field resistance to root rot was 'Summit', which has a reputation for resistance (Lévesque and Daubeny, 1999). 'Newburgh' also showed resistance in this and other studies (Lévesque and Daubeny, 1999), but showed sensitivity to higher disease pressure at Vancouver. 'Cascade Bounty' had resistance similar to that of 'Newburgh' in the greenhouse, which agrees with earlier field observations (Moore and Finn, 2007), although confirmation is needed from a replicated field study.

Pattison et al. (2004) observed that a cultivar's ability to generate new primocanes from root tissue rather than existing crown tissue may allow it to recover from moderate or intermittent root rot infection in the field. However, such a recovery mechanism may not be apparent in a short-term greenhouse test with high disease pressure, leading to a susceptibility rating higher than observed in the field (Pattison et al., 2004). This may have been a factor in the response of 'Cascade Dawn', and to some extent, 'Cascade Delight', which had high greenhouse root and shoot ratings but showed partial field resistance. 'Cascade Dawn' had more total canes than either 'Newburgh' or 'Summit' all 3 years at Puyallup, but its increasing infection levels over time and sharp decline in cane number in Vancouver indicated susceptibility to the disease. Therefore, it was crucial to gather 3 or more years of field data to assess relative susceptibility to root rot in this study. Both 'Cascade Dawn' and 'Cascade Delight' were described previously as possessing some field resistance (Moore, 2004, 2006). The high susceptibility of 'Malahat' and 'Cowichan' is consistent with previous observations (Lévesque and Daubeny, 1999; Pattison and Weber, 2005). 'Cascade Nectar', 'Kitsilano', and WSU 1226 also had very high susceptibility in this study. 'Meeker', 'Tulameen', and 'Willamette' were found to be susceptible to root rot, consistent with earlier reports (Barritt et al., 1981; Laun and Zinkernagel, 1993; Lévesque and Daubeny, 1999).

Inoculum concentration influenced greenhouse response only slightly and the 50 $\mathrm{mg} \cdot \mathrm{mL}^{-1}$ level correlated most closely with field variables. Testing at several inoculum levels was time-consuming and did not provide 
Table 3. Root and shoot ratings of 14 red raspberry genotypes inoculated with $50 \mathrm{mg} \cdot \mathrm{mL}^{-1}$ Phytophthora fragariae var. rubi mycelium suspension compared with noninoculated control.

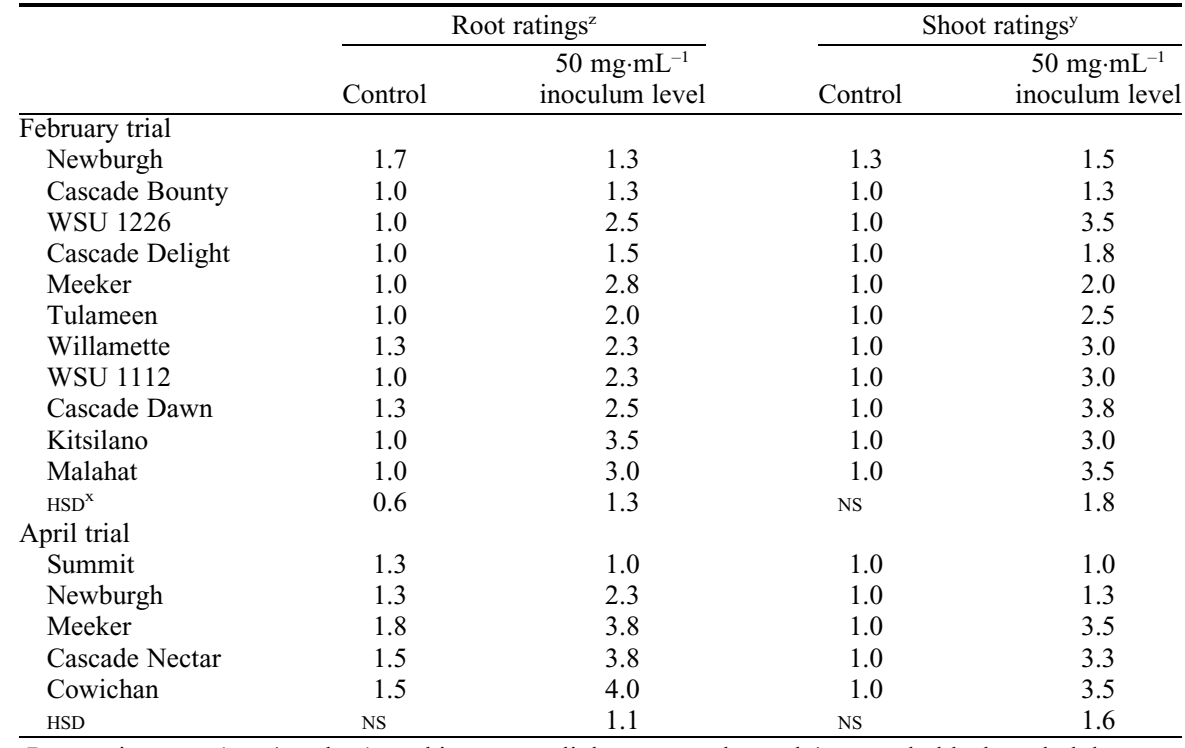

${ }^{\mathrm{z}}$ Root rating on a 1 to 4 scale; $1=$ white or very light cream color and $4=$ mostly black or dark brown.

${ }^{\mathrm{y}}$ Shoot rating on a 1 to 4 scale; 1 = green and vigorous growth, 2 to $3=$ degrees of chlorosis and wilting, and $4=$ necrotic and no growth.

${ }^{\mathrm{x}}$ Comparisons that exceed Tukey's honestly significant difference (HSD) are significantly different at $P=0.05$.

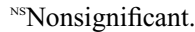

Table 4. Correlation coefficients $(r)$ of field root rot evaluation criteria and February greenhouse root rating for 10 raspberry genotypes $(n=10)$.

\begin{tabular}{lccr}
\hline & \multicolumn{3}{c}{$\begin{array}{c}\text { Inoculum level } \\
\text { (mg mycelia/mL) }\end{array}$} \\
\cline { 2 - 4 } & 10 & 50 & 200 \\
\hline Puyallup 2006 & & & \\
Total number of canes & -0.60 & $-0.72 *$ & -0.49 \\
Percent infection & $0.70^{*}$ & $0.83^{* *}$ & 0.55 \\
Cane height & -0.56 & $-0.65^{*}$ & -0.39 \\
Vancouver 2006 & & & \\
Total number of canes & -0.44 & $-0.70^{*}$ & -0.30 \\
Percent infection & 0.40 & $0.68^{*}$ & 0.33 \\
Cane height & -0.50 & $-0.71^{*}$ & -0.30 \\
\hline **** Significant at $P \leq 0.05$ & 0.01 & respectively.
\end{tabular}

*,** Significant at $P \leq 0.05$ or 0.01 , respectively.

additional information about relative sensitivity to disease pressure. Root rating gave better cultivar differentiation than other greenhouse response variables as observed by Laun and Zinkernagel (1993). Root rating was easy to measure and proved consistent with field observations. Other greenhouse evaluation criteria were of minimal use in identifying genotypes with field resistance. The root rot symptoms seen in the small April 'Newburgh' plants corroborated previous observations that trials of very small plants overestimate root rot susceptibility (Laun and Zinkernagel, 1993; Wilcox et al., 1999a).

Besides $P$. fragariae var. rubi, several other Phytophthora, Rhizoctonia, Fusarium, Pythium, and Cylindrocarpon species are pathogenic on red raspberry, acting individually or synergistically (Duncan and Kennedy, 1989; Schilder, 2007; Wilcox, 1989; You et al., 2006). The activity of some of these pathogens in the field may partially account for the differences in genotypic
Kempler, C., H.A. Daubeny, B. Harding, and C.G. Kowalenko. 2005. 'Cowichan' red raspberry. HortScience 40:1916-1918.

Kennedy, D.M. and J.M. Duncan. 1991. Methods for assessing the resistance of raspberry genotypes to Phytophthora root rot. Plant Pathol. 40:387-394.

Laun, N. and V. Zinkernagel. 1993. Methods of screening raspberries for resistance to phytophthora root rot. Acta Hort. 352:569-578.

Lévesque, C.A. and H.A. Daubeny. 1999. Variation in reaction to Phytophthora fragariae var. rubi in raspberry genotypes. Acta Hort. 505:231-235.

Maloney, K., M. Pritts, W. Wilcox, and M.J. Kelly. 2005. Suppression of phytophthora root rot in red raspberries with cultural practices and soil amendments. HortScience 40:1790-1795.

Moore, P.P. 2004. 'Cascade Delight' red raspberry. HortScience 39:185-187.

Moore, P.P. 2006. 'Cascade Dawn' red raspberry. HortScience 41:857-859.

Moore, P.P. and C.E. Finn. 2007. 'Cascade Bounty' red raspberry. HortScience 42:393-396.

Pattison, J.A. and C.A. Weber. 2005. Evaluation of red raspberry cultivars for resistance to phytophthora root rot. J. Amer. Pomol. Soc. 59:50 56.

Pattison, J.A., W.F. Wilcox, and C.A. Weber. 2004. Assessing the resistance of red raspberry (Rubus idaeus L.) genotypes to Phytophthora fragariae var. rubi in hydroponic culture. HortScience 39:1553-1556.

Pinkerton, J.N., K.L. Ivors, P.W. Reeser, P.R. Bristow, and G.E. Windom. 2002. The use of soil solarization for the management of soilborne plant pathogens in strawberry and red raspberry production. Plant Dis. 86:645-651.

Schilder, A.C. 2007. Determining the role of Rhizoctonia, Pythium, and Cylindrocarpon in replant disorder of raspberry. North Amer. Bramble Growers Assn. 2007 Conf. Proc. 25-34.

Valois, D., K. Fayad, T. Barasubiye, M. Garon, C. Déry, R. Brzezinski, and C. Beaulieu. 1996. Glucanolytic actinomycetes antagonistic to Phytophthora fragariae var. rubi, the causal agent of raspberry root rot. Appl. Environ. Microbiol. 62:1630-1635.

Washington Red Raspberry Commission. 2004. Red raspberry varieties. 11 May 2007. <http:// www.red-raspberry.org/raspberry/variety.html $>$.

Washington State University. 2006. Whatcom County IPM Project, Phytophthora fragariae var. rubi PCR test results. Whatcom County Extension, Bellingham, WA. 22 May 2007. $<$ http://whatcomwsu.edu/ag/IPM/phytophthora results.htm>.

Wilcox, W.F. 1989. Identity, virulence, and isolation frequency of seven Phytophthora spp. causing root rot of raspberry in New York. Phytopathology 79:93-101.

Wilcox, W.F., J.R. Nevill, and J.A. Burr. 1999a. Susceptibility of red, black, and purple raspberry cultivars to three Phytophthora species under greenhouse and field conditions. Acta Hort. 505:241-247.

Wilcox, W.F., M.P. Pritts, and M.J. Kelly. 1999b. Integrated control of phytophthora root rot of red raspberry. Plant Dis. 83:1149-1154.

Wilcox, W.F., P.H. Scott, D.M. Kennedy, J.M. Duncan, C.M. Brasier, and E.M. Hansen. 1993. Identity of a Phytophthora species attacking raspberry in Europe and North America. Mycol. Res. 97:817-831.

You, R., M. Sweeney, C. Kempler, and S. Sabaratnam. 2006. Investigation of root rot complex on raspberries grown in the lower Fraser valley of British Columbia. Can. J. Plant Pathol. 28:370 (abstr.). 